\title{
Providing with Training of IT-Personnel for High- Tech Industrial Enterprises in the Digitalization of Social-Economic Systems
}

\author{
Anna S. Melnikova \\ Perm National Research Polytechnic University \\ Perm, Russia \\ dew244@yandex.ru
}

\author{
Maria N. Eltsova \\ Perm National Research Polytechnic University \\ Perm, Russia \\ maria_eltsova@mail.ru
}

\author{
Alexander K. Mikhailov \\ Perm National Research Polytechnic University \\ Perm, Russia \\ mak1801@bk.ru
}

\begin{abstract}
The paper is focused on studying issues of IT education, training IT personnel and implementing an IT career in the industrial and economic segment, taking into account the current paradigm of Industry 4.0 and preparation for the formation of Industry 5.0. The scheme of the implementing the stages of education and / or advanced training of employees in the digitalization of industrial and economic systems has been compiled and analyzed. We identified problems related to the lack of vocational education in the personnel elevator.
\end{abstract}

Keywords-personnel digitalization; IT education; personnel elevator; digital economics; real sector of economics; Society 4.0 and 5.0; training highly-qualified specialists

\section{INTRODUCTION}

At the beginning of the XXI century, transformation processes of digitalization of all systems of society's life take place at the world level: in social-economic structures, in the industrial and financial sectors. In connection with these trends, it becomes essential to plan and provide with training of digital personnel with the competencies of high-tech specialists able to work in the new IT vector and to meet all the requirements of employers in the existing information technology space, in the exogenous and endogenous environment of the employee's workplace.

The paper aims to develop an career elevator for providing digital personnel for the IT industry, to consider all levels of education with examples of leading educational institutions in the areas of training highly qualified specialists which posess information and communication technology competencies and are in demand in today's labor market.

The research basis included tools and methods aimed at studying ergonomic processes in a tender with digitalization of personnel, especially, system-centric and environment-oriented approaches, as well as classic methods: a hypotheticaldeductive method of scientific knowledge, a method of analysis and comparison and a method of graphical modeling.
Polemic issues regarding the planning and personnel training, the level of the education and the necessary degree of qualification have been conducted among scientists from time immemorial. The topic of studying digitalization of personnel is research worth and is presented in the works of both Russian scientists $[1,2,3,4,5]$ and foreign authors $[6,7,8,9]$.

\section{THE CONCEPT}

This study combines such versatile components as: "man technology - society". Thereby the authors are intended to consider the synergy of these subjects through the prism of a cognitive philosophy, namely to present the interaction of human resources, technological processes and social environment in the context two cycles of Society 4.0 and Society 5.0 since the main object of the present study is personnel and their vector of digital development in the industry 4.0 paradigm and the transition to Industry 5.0 (Table 1).

TABLE I. CHARACTERISTICS OF SOCIETY 4.0 AND SOCIETY 5.0 IN TERMS OF PERSONNEL DIGITALIZATION [11]

\begin{tabular}{|c|c|c|}
\hline $\begin{array}{l}\text { Depending } \\
\text { on the } \\
\text { work } \\
\text { performed }\end{array}$ & $\begin{array}{c}\text { Society } 4.0 \\
(2011-2015)\end{array}$ & $\begin{array}{c}\text { Society } 5.0 \\
(2016-\text { now })\end{array}$ \\
\hline $\begin{array}{l}\text { Industrial } \\
\text { Production } \\
\text { staff }\end{array}$ & $\begin{array}{l}\text { - Acting of an individual } \\
\text { to optimize a workplace } \\
\text { by means of applying } \\
\text { the information and } \\
\text { communication } \\
\text { technologies. } \\
\text { - Finding solutions to } \\
\text { individual problems } \\
\text { related to job search } \\
\text { restrictions due to } \\
\text { social-demographic } \\
\text { characteristics. }\end{array}$ & $\begin{array}{l}\text { - Modernizing the society } \\
\text { through merging the cyberspace } \\
\text { and the real world. } \\
\text { - Developing the human labor } \\
\text { on the global Internet, ensuring } \\
\text { the processes of safe activities. } \\
\text { - Lacking the socio- } \\
\text { demographic barriers, no age / } \\
\text { gender restrictions. } \\
\text { - Ensuring human well-being in } \\
\text { society through developing } \\
\text { social, environmental, } \\
\text { informational and economic } \\
\text { potential of the real and } \\
\text { financial sectors. }\end{array}$ \\
\hline
\end{tabular}




\begin{tabular}{|c|c|c|}
\hline $\begin{array}{l}\text { Depending } \\
\text { on the } \\
\text { work } \\
\text { performed }\end{array}$ & $\begin{array}{l}\text { Society 4.0 } \\
(2011-2015)\end{array}$ & $\begin{array}{c}\text { Society } 5.0 \\
(2016-\text { now })\end{array}$ \\
\hline $\begin{array}{l}\text { Administra } \\
\text { tive staff }\end{array}$ & $\begin{array}{l}\text { - Human working with a } \\
\text { computer on the Internet } \\
\text { (Consistent, but not } \\
\text { safe). } \\
\text { - Emerging the } \\
\text { informatization process } \\
\text { in the workplace. }\end{array}$ & $\begin{array}{l}\text { - Modernizing the society } \\
\text { through merging the cyberspace } \\
\text { and the real world. } \\
\text { - Working via the Internet in a } \\
\text { safe manner. } \\
\text { - Operating new resources, } \\
\text { among them information, which } \\
\text { allows to reach a new level of } \\
\text { development of society, } \\
\text { technologies, etc. in general, } \\
\text { and to develop the quality of } \\
\text { life of an individual and his } \\
\text { professional capabilities in } \\
\text { particular. }\end{array}$ \\
\hline
\end{tabular}

After a comparative analysis of Table 1, we highlight the features of the fifth stage of digitalization of personnel: a new level of digital capabilities, a high degree of convergence of cyberspace and the physical environment, ensuring of sustainable economic growth and security processes of human interaction with the information space.

Because of the expansion of digital resources in modern society, it is possible to implement the priority projects to modernize the personnel system by introducing the information and communication technologies and artificial intelligence. The interaction of cyberspace and physical space gives a start in the development of an individual's dialog with a mass audience, with work in the information segment, with a large amount of data, a new level of human-labor capabilities with technical and technological support of the enterprise.

The best personnel development in the priority digital vector is impossible without the education and advanced training of specialists in the field of information and communication technologies.

By 2024, the Government of the Russian Federation intends to bring about a comprehensive digital transformation of the Russian economy and social sphere. For this purpose, it is necessary to develop at the legislative level the regulation and provision of digital technologies for real sector entities, to modernize the digital infrastructure, to implement digital practices in all key areas of the economy and public administration, as well as to organize personnel training for the transition period [12].

According to the Decree of the Government of the Russian Federation dated March 2, 2019 No. 234 The National Program "Digital Economy of the Russian Federation", there has been drawn up a scheme for implementing the education and advanced training system aimed at providing with highly qualified specialists in the field of digitalization. The scheme is presented in Fig. 1.

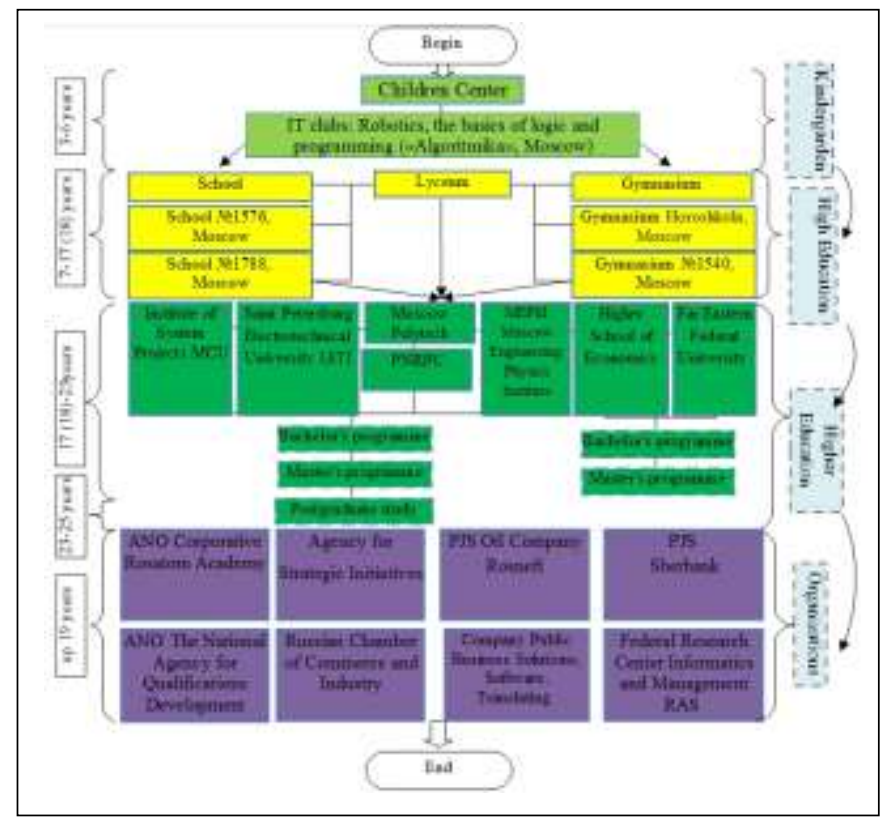

Fig. 1. A personnel elevator for providing high-tech industrial enterprises in the digitalization of social-economic systems with IT-workers[14]

Analysis of Fig. 1. allows us to conclude that at each stage of the education process, the personnel development begins in the aspect of its "digitization". An individual will be able to study and track the development of the digital economy and information and communication technologies, to interpret the data and to forecasts the development of social-economic processes, to develop and to apply in practice algorithms for working with a large volume of databases, to combine a programming language, mathematical modeling and socialeconomic processes when solving non-standard managerial tasks [13]. All these competencies are provided to graduates of leading higher educational institutions who in turn work in the fields of training bachelor, master and postgraduate students in the concept of training highly-qualified IT-specialists.

Among the popular training programs related to the IT industry, it is necessary to note: "Information Management Systems", "Information Systems and Technologies in Business" (St. Petersburg Electrotechnical University "LETI"); "Digital Innovation in Enterprise Management" (HSE); "Secure High-Performance Computing Systems" (NRNU MEPhI); "Applied informatics in enterprise management" (FEFU) as well as other master programs, for example "Conceptual design and engineering to improve energy efficiency" (PNRPU) [13].

There are the actual disciplines supported by partner enterprises: "Information systems and digital content processing technologies", "Information and automated information processing and management systems", "Information technologies in the media industry and design", "Augmented and virtual reality technologies in the media industry" ("Moscow Polytechnic University"). It should be noted a number of enterprises where the students of leading engineering universities of the country have a practical training. In the future these graduates are hired by these enterprises, so the following high-tech companies are already 
providing themselves with IT-specialists: the state corporation ROSTEKH, JSC ROSELECTRONIKA, JSC Scientific Research Institute of Software, Concern Okeanpribor JSC, Scientific and Engineering Center of St. Petersburg Electrotechnical University JSC, Public Business Solutions, Software, Translating company, ABBYY and many other organizations (see Fig. 1).

Notable is that there is no stage of a vocational education, namely training at colleges and technical schools in the scheme, which, firstly, negatively affects the entire education and training system in the digital segment and, secondly, these graduates cannot acquire decent knowledge as IT-staff taking into account up to date and onrush technologies. The curricula of colleges and technical schools contain only basic disciplines related to information and communication technologies. The same problem is noted at the level of school education: it is significant for the most schools with the exception of specialized secondary education institutions shown in the diagram (see Fig. 1) where the students of primary classes obtain optional lessons related to new IT technologies and licensed software. These schools are attracting leading university employees to deliver the IT-subjects to high school students. A positive determinant of the lack of a level of a vocational education in a personnel elevator can only be the authorities' desire to stimulate high school graduates to enter the country's leading engineering universities.

\section{CONCLUSION}

The paper carried out an integrated approach of the stages of a personnel digitalization and a comparative analysis of Society 4.0 and Society 5.0. We have compiled and analyzed the scheme of the implementing the stages of education and / or advanced training of employees in the digitalization of industrial and economic systems. There were identified problems related to the lack of vocational education in the personnel elevator.

The paper aimed to fully and comprehensively formulate the opinions of specialists in the social-economic, industrial and educational sectors on the trends and prospects of digitalization of personnel at its various stages, to familiarize themselves with the main IT-curricula that contribute to the modernizing the personnel during automation and "digitization" of the workplace, as well as to acquaint with positive and negative factors in the existing training system.

This paper will be of special interest to the students whose future profession would be related to information and communication technologies, to specialists in the field of digitalization of personnel, to administrative and managerial personnel, and also to employees of the human resources department in connection with their responsibilities for finding applicants for vacant jobs and for advanced training of company employees.

The digitalization of personnel and the preparation of society for this program is the most important process in the modern world. The influence of digitalization trends leads to changes in all structures of the society. It was the national program "Digital Economy of the Russian Federation" that was especially developed to adapt to digital technologies and to improve digital literacy. The presence of highly qualified and educated IT-specialists in the country is an excellent opportunity for Russia to improve its position in the digital industrial and economic market.

\section{REFERENCES}

[1] Gretchenko A.A. Podgotovka vysokokvalifitsirovannykh kadrov dlya tsifrovoy ekonomiki. [Training of highly qualified personnel for the digital economy]. Rossiya: tendentsii $i$ perspektivy razvitiya [Russia: trends and development prospects]. 2018. Pp. 824-827. (in Russian)

[2] Mekhdiev Sh.Z. Formirovanie sistemy kvalifitsirovannykh kadrov usloviyakh tsifrovoy ekonomiki. [Forming a system of qualified personnel in the digital economy]. Vestnik evraziyskoy nauki [Bulletin of Eurasian science]. 2018. T. 10. № 6. Pp. 377-402. (in Russian)

[3] Borisova V.V. Podgotovka kadrov dlya tsifrovoy ekonomiki [Training for the digital economy]. Sovershenstvovanie uchebno-metodicheskoy raboty $v$ universitete $v$ izmenyayushcheysya srede [Improving the educational and methodical work at the university in a changing environment]: Materialy II natsional'noy mezhvuzovskoy nauchnometodicheskoy konferentsii [Proc. of the $2^{\text {nd }}$ national interuniversity scientific-methodical conference], SpbGEU, Sankt-Petersburg, 29-30 yanvarya 2018 g. / Sankt-Petersburg, 2018. Pp. 42-47. (in Russian)

[4] Saak A.E., Pakhomov E.V., Tyushnyakov V.N. Informatsionnye tekhnologii upravleniya [Information Technology in Management] SPb.: Piter Publ., 2005. 320 p. (in Russian)

[5] Khalin V.G, Chernova G.V. Tsifrovizatsiya i ee vliyanie na rossiyskuyu ekonomiku $i$ obshchestvo: preimushchestva, vyzovy, ugrozy $i$ riski. [Digitalization and its impact on the Russian economy and society: advantages, challenges, threats and risks]. Upravlencheskoe konsul'tirovanie [Management Consulting]. 2018. № 10(118) Pp. 46-63. (in Russian)

[6] Stolterman E., Fors A.C. Information Technology and the Good Life // Information Systems Research. 2004. P. 687-692

[7] Gray J., Rumpe B. Models for the Digital Transformation. Soft ware \& Systems Modeling. 2017. Vol. 16. N. 2. P. 307-308.

[8] Matt C., Hess T., Benlian A. Digital Transformation Strategies. Business and Information Systems Engineering. 2015. Vol. 57. N. 5. P. 339-343.

[9] Kopoulos A. Flight Risk Signals Uncovered: What Makes Employees Leave? EmpoyeeConnect [Elektronnyy resurs]. URL: https://www.employeeconnect.com/blog/

[10] Kulik C.T., Bainbridge H.T.J. HR and the line: the distribution of HR activities in Australian organizations. Asia pacific journal of human resources. 2006. N. 2. Pp. 240-256.

[11] Uemura N. Obshchestvo 5.0: Vzglyad Mitsubishi Electric. [Mitsubishi Electric Look] Ekonomicheskie strategii. [Economic Strategies] 2017. № 4. Pp. 2-11. (in Russian)

[12] Ofitsial'nyy sayt programmy «Tsifrovaya ekonomika Rossiyskoy Federatsii» [Official web site of the programm Digital economy of the Russian Federation]. Available at: https://data-economy.ru/ (in Russian)

[13] Petrochenkov A., Lyakhomskii A., Perfilieva E., Bochkarev S. Conceptual design and engineering strategies to increase energy efficiency at enterprises: Research, technologies and personnel. IV Forum Strategic Partnership of Universities and Enterprises of Hi-Tech Branches (Science. Education. Innovations) [Electronic resource]: St. Petersburg, Nov. 1113, 2015. IEEE Russia North-West section. [S. 1.] IEEE, 2015. P. 44-47. (in Russian)

[14] Postanovlenie o sisteme upravleniya realizatsiey natsional'noy programmy "Tsifrovaya ekonomika Rossiyskoy Federatsii»: ot 02.03.2019 g. №234. [Resolution on the system for managing the implementation of the national program Digital Economy of the Russian Federation: No. 234 of 03/02/2019]. Sobranie Zakonodatel'stva RF [Collection of the Legislation of the Russian Federation]. 2019. №16. (in Russian) 